\title{
MediaMorfosis
}

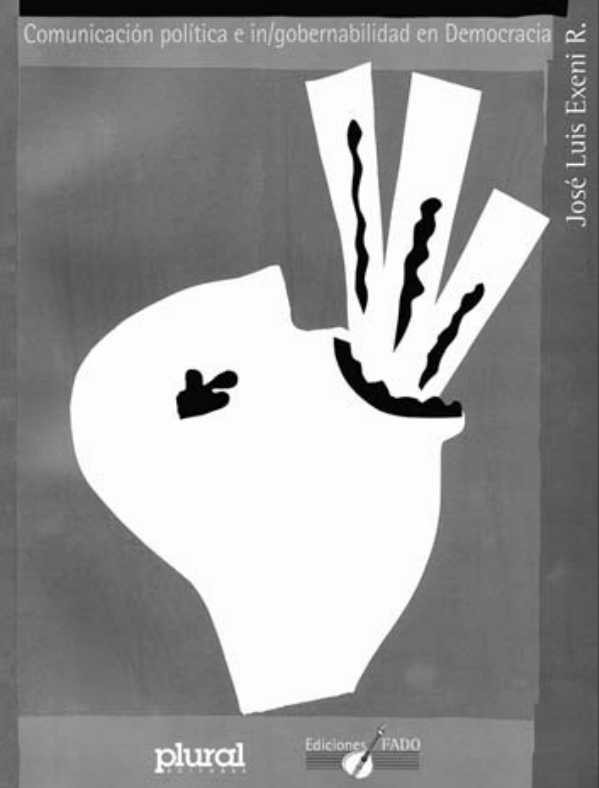

José Luis Exeni

MediaMorfosis: Comunicación

Política e in/gobernabilidad

en democracia

La Paz, Bolivia:

Plural Editores, 2005.

283 páginas

Márcia Yukiko Matsuuchi Duarte

- Mestre em Comunicação Social pela Universidade de Brasília (UnB)

- Advogada e relações-públicas

- Atua na Secretaria de Pesquisa e Opinião Pública do Senado Federal

- yukiko@senado.gov.br 


\section{Comunicação na política e in/governabilidade}

$E^{n}$ m tempos de grandes e contínuas mudanças políticas no Brasil e no mundo, que já se estendem há mais de 15 anos, de freqüentes reestruturações efetuadas pelos meios de comunicação de massa e das inovações promovidas pelas novas tecnologias, a obra MediaMorfosis: Comunicación Política e in/gobernabilidad en democracia, de José Luis Exeni, é um consistente guia para aqueles que se dedicam a estudar a Comunicação Política e todas as surpreendentes formas que esse campo pode assumir. Extremamente cuidadoso e detalhista, o autor demonstra uma preocupação permanente em analisar a influência das mídias sobre a política e, principalmente, sobre os efeitos desse processo cada vez mais intenso e simbiótico na consolidação ou erosão das instituições democráticas e na caracterização/atuação de seus atores.

Tema inesgotável para os estudiosos da Comunicação e da Ciência Política, a relação entre política e o papel desempenhado pelas várias mídias tem sido abordada de diversificadas formas e sob os mais variados ângulos, sendo a maioria dos trabalhos dedicados à descrição de casos específicos, observados com base em diferentes enfoques metodológicos. Mas ainda são poucos os trabalhos dedicados integralmente à análise teórica do tema, com foco na reflexão conceitual. E é justamente nesse ponto que reside o melhor de MediaMorfosis. O seu foco está centrado no esforço de pensar e avaliar as tendências e características fundamentais da relação entre comunicação e política, escapando da sempre presente tentação oferecida pelas teorias interpretativas que polarizam, simplificam e, em geral, acabam por empobrecer as análises sobre os meios de comunicação e suas relações com o poder.

O grande mérito da obra de Exeni não é o de apontar respostas prontas e perfeitas para as inúmeras questões relativas à influência dos meios de comunicação na política e na governabilidade, mas, antes, o de identificar os pontos essenciais necessários para compreender, em cada caso concreto, a importância do papel das mídias nos assuntos de ordem pública.

Doutor em Ciência Política, mestre em Ciências Sociais e consultor do Escritório Regional de Comunicação para a América Latina da Unesco, Exeni propõe uma indagação teórica e conceitual sobre como a ação dos meios de comunicação está transformando, por um lado, o sistema político e, por outra parte, o exercício da função de Governo. Esta última função é tratada pelo autor tanto no seu aspecto positivo e mais frequentemente citado, a governabilidade, quanto no negativo e geralmente esquecido - a "ingovernabilidade". Muitos e atuais são os problemas de investigação le- 
vantados pelo autor como, por exemplo, quão relevante é a ação mediática para a "in/governabilidade" e, ainda, quão "in/governáveis" são as mídias concebidas não somente como difusoras e palco da política, assim também como atores estratégicos? Debate relevante e atual, pelo que se percebe diariamente.

Na essência, para compreender a comunicação política e seus efeitos no sistema político e na "in/ governabilidade", o autor apresenta um texto na modalidade de ensaio; um estudo de caráter exploratório cujo objeto de investigação é abordado numa perspectiva analítico-conceitual e que não se preocupa em apresentar casos concretos, embora faça referências a várias obras que tratam de estudos empíricos. De fato, o suporte teórico do texto seguiu um itinerário lógico de tratamento temático, cuja fonte de informação predominante foi a bibliográfica, com revisão da literatura mais relevante sobre o tema, a realização de uma conexão analítica e comparativa de categorias centrais e a sistematização de uma proposta de leitura.

Estruturalmente, a apresentação do livro está organizada em duas partes principais. Na primeira metade, o autor desenvolve a discussão sobre a comunicação política abordando seis temas principais que abrangem questões como os efeitos dos meios de comunicação de massa, o papel dos vários atores da comunicação política, o processo de formação da agenda informativa, a função do agenda setting etc. Na segunda, desenvolve uma análise das conexões entre a comunicação política e o problema da "in/governabilidade" na democracia, também discorrendo sobre mais seis temas essenciais como, por exemplo, a "governabilidade mediática", a "comunicabilidade", a resposta governamental, a influência da construção da agenda informativa e as demandas sociais.

Entre os méritos da obra de Exeni podemos destacar três pontos fundamentais. O primeiro, de oferecer ao leitor um texto claro, didático e objetivo, adotando uma postura de conversação, de apresentação e discussão sobre idéias que remetem a uma reflexão sobre o tema. O segundo mérito consiste em proporcionar ao leitor um rico material informativo, ilustrando as principais tipologias científicas, de forma acessível e de modo a permitir que cada interessado, a partir da realidade e dados apresentados, realize sua própria avaliação. O terceiro consiste na possibilidade dada ao leitor de ler separadamente, caso seus interesses sejam dissociados, a primeira parte Comunicação Política e a segunda parte - Governabilidade, pois os temas são apresentados de modo independente.

Ao final da leitura, a conclusão central é que a obra MediaMorfosis representa uma importante proposta de reflexão sobre a relação entre Comunicação e Política, pois oferece um instrumental teórico indispensável para o entendimento de questões fundamentais como governança, sistemas representativos, democracia de audiência, agenda pública etc. Com MediaMorfosis, Exeni completa o trabalho iniciado em seu livro an- 
terior intitulado Políticas de Comunicación: retos y señales para no renunciar a la utopia, tendo como traço comum a análise e exposição conceitual sobre verdades e mentiras do poder mediático e suas relações com os sistemas políticos.

A publicação, em espanhol e, portanto, somente adquirida por encomenda (plural@acelerate.com), enriquece o referencial teórico da Comunicação e da Ciência Política, contribuindo sobremaneira para o desenvolvimento dos estudos da política, dos sistemas representativos e, conseqüentemente, do novo conceito de governança. Que a vigorosa e instigante reconstrução conceitual e interpretativa de Exeni possa deixar entre nós idéias frutíferas sobre a importância do papel das mídias na verdadeira ação política em prol da liberdade e do fortalecimento da democracia. 